\title{
Ruthenium Catalysts in Regioselective Hydrogenative Metathesis
}

\author{
Vaezeh Fathi Vavsari* (D) \\ Peptide Chemistry Research Institute, K. N. Toosi University of Technology, P.O. Box 15875-4416, Tehran, Iran \\ v.fathi83@yahoo.com
}

\begin{abstract}
Received: 10.04.2021
Accepted after revision: 29.04.2021

Published online: 31.05 .2021

DOI: 10.1055/s-0040-1706043; Art ID: so-2021-d0021-spot

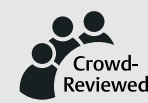

License terms: CCO

(c) 2021. The Author(s). This is an open access article published by Thieme under the terms of the Creative Commons Attribution-NonDerivative-NonCommercial-License, permitting copying and reproduction so long as the original work is given appropriate credit. Contents may not be used for commercial purposes or adapted, remixed, transformed or built upon. (https://creativecommons.org/licenses/by-nc-nd/4.0/)
\end{abstract}

Abstract Key words catalysis, hydrogenation, metathesis, regioselectivity, ruthenium catalysts

Metathesis is an efficient way to build $\mathrm{C}-\mathrm{C}$ bonds and to construct complex organic structures. ${ }^{1}$ Molybdenum and tungsten catalysts are highly effective in metathesis of numerous olefins, however, their complexes are extremely sensitive towards air and moisture. ${ }^{2}$ As a consequence, moisture- and air-compatible ruthenium complexes having considerably improved characteristics were developed in the late 1990s. Among these new catalysts, the rutheniumcontaining Grubbs catalysts are very attractive due to their stability and modifiable structures, with various organic and inorganic groups, so that several generations of Grubbs catalyst have become commercially available. ${ }^{3}$ Rutheniumbased catalysts are currently used in three types of metathesis: ${ }^{4}$ intermolecular hydrogenative metathesis between two alkenes to give alkanes, intramolecular hydrogenative metathesis of a diene structure to obtain cycloalkanes, and intramolecular hydrogenative metathesis of an alkenealkyne including structure to obtain cycloalkenes or alternative heterocycles (Scheme 1).

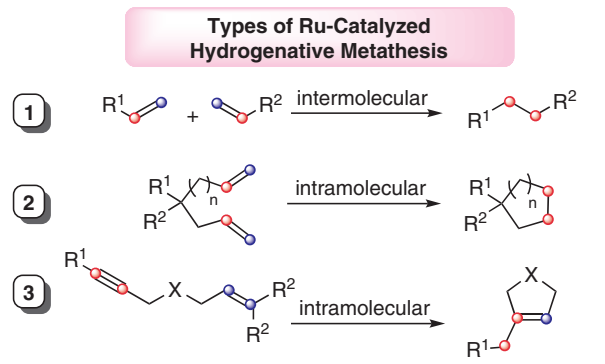

Scheme 1 Three classes of Ru-based hydrogenative metathesis

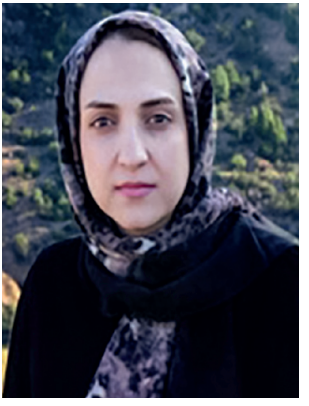

Vaezeh Fathi Vavsari was born in 1983 in Iran. She received her BSC degree in applied chemistry from the Ferdowsi University of Mashhad (2009) and her MSc degree in organic chemistry at the K. N. Toosi University of Technology (2013). She received her PhD degree in organic chemistry from Alzahra University in 2016. Her doctoral dissertation was concerned with surface functionalization of nanoporous materials by organic compounds and their application in the synthesis of biologically active compounds. She currently works as a researcher at the Peptide Chemistry Research Institute, K. N. Toosi University of Technology, Tehran, Iran. Her present research interests include organic synthesis, designing of novel multicomponent reactions, asymmetric synthesis, and also peptide chemistry.

The selective hydrogenation of a specific functional group in the presence of other potentially reducible functionalities is challenging. It has recently been found that ruthenium complexes can selectively catalyze such selective hydrogenations. ${ }^{5}$ Various ruthenium-catalyzed hydrogenations have been reported, such as hydrogenation of internal alkynes to obtain (E)-alkenes through trans-delivery of hydrogen, ${ }^{6}$ hydrogenation of unsaturated aldehydes and carboxylic acids to unsaturated alcohols, ${ }^{7}$ enantioselective hydrogenation of hydrazones, ${ }^{8}$ and levulinic acid hydrogenation to $\gamma$-valerolactone. ${ }^{9}$

Furthermore, ruthenium metathesis can be coupled with selective hydrogenation in a one-pot sequential protocol. This is possible by the use of a ruthenium catalyst in the presence of a hydrogen source such as hydrogen gas or formic acid. 


\section{Abstracts}

\section{(A) Sequential Crossed Metathesis-Aldehyde Reduction} catalyst $\mathbf{M} \mathbf{1}^{10}$ in a mixture of surfactants can catalyze one-pot cross-metathesis/transfer-hydrogenation reactions of 10-undecenal 2 with methyl acrylate $\mathbf{1}$ in water as solvent. This conversion produces $(E)$-methyl-12-hydroxydodec-2-enoate 3 in 65-72\% yield when run under air in a mixture of nonionic Tween 20 and cationic dodecyl trimethyl ammonium chloride (DTMAC) as surfactants. ${ }^{11}$
An emulsion of first-generation ruthenium indenylidene olefin metathesis

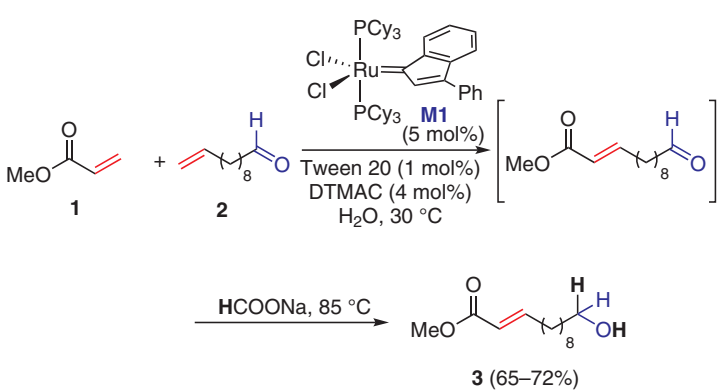

\section{(B) Cyclization Hydrogenative Metathesis}

One of the simplest routes to achieve substituted cyclopentanes and cycloheptanes is the use of dienes $\mathbf{4}$ in the Ru-catalyzed tandem ring-closing metathesis/hydrogenative reaction. ${ }^{12}$ Second-generation Grubbs catalyst $\mathbf{~} 2^{13}$ gives the cyclic products $\mathbf{5}$ in a highly regio- and chemoselective manner. In this case, formic acid plays the role of hydrogen donor. Such products $\mathbf{5}$ have been converted into the drugs Carbetapentane ${ }^{\circledR 14}$ and Fludilate ${ }^{\circledR} .{ }^{15}$

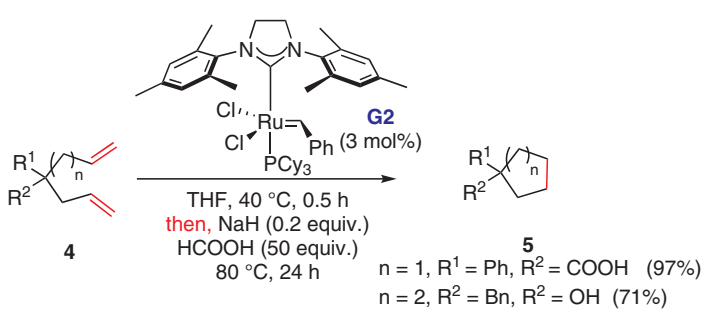

\section{(C) Polymerization Hydrogenative Metathesis}

Inspired by the above-mentioned examples, the polymerization reaction of dimethyl-5-norbornene-2,3-dicarboxylate $\mathbf{6}$ with allyl-PEG5000 methyl ether 7 was accomplished in a Schlenk flask using a Grubbs third-generation catalyst through ring-opening metathesis polymerization/cross metathesis, followed by sequential one-pot hydrogenation reaction using formic acid. This reaction led to PEG end-capped polynorbornene. ${ }^{16}$

\section{(D) Ene-Yne Hydrogenative Metathesis}

gem-Hydrogenation of propargyl alcohol/ether compounds 9 and 11 catalyzed by chloro(pentamethylcyclopentadienyl)ruthenium(II) tetramer, $\left[\mathrm{Cp}{ }^{*} \mathrm{RuCl}\right]_{4}$, led to the formation of cyclopropenes 10 and 12, respectively, passing via piano-stool ruthenium carbenes. The substitutions of the substrates affect the outcomes of this reaction, furnishing the target cyclopropenes and/or bicyclo[3.1.0] hexanes. ${ }^{17}$

(1)




(E) Ene-Ynone Hydrogenative Metathesis
Compound $\mathbf{1 3}$ can be synthesized from readily available 2-acetyl-5-methyl-
furan in a six-step reaction sequence. Hydrogenative metathesis of $\mathbf{1 3}$ was
catalyzed by ruthenium catalyst $\mathbf{1 4}$ to furnish adduct 15, which was readily
converted into the natural product sinularone $\mathrm{F}$ under standard conditions. It
should be noted that the SEM derivative of $\mathbf{1 3}$ gave only trace amounts of the
metathesis cyclopentenone 15, while TBS and TMS derivatives of $\mathbf{1 3}$ were
successfully cyclized to 15. ${ }^{18}$

\section{Conflict of Interest}

The author declares no conflict of interest.

\section{References}

(1) (a) Cheng-Sánchez, I.; Sarabia, F. Synthesis 2018, 50, 3749. (b) Becker, M. R.; Watson, R. B.; Schindler, C. S. Chem. Soc. Rev. 2018, 47, 7867.

(2) Lefebvre, F.; Bouhoute, Y.; Szeto, K. C.; Merle, N.; de Mallmann, A.; Gauvin, R.; Taoufik, M. Olefin Metathesis by Group VI $(M o, W)$ Metal Compounds, In Alkenes; IntechOpen: London, 2017.

(3) (a) Nahra, F.; Cazin, C. S. J. Chem. Soc. Rev. 2021, 50, 3094. (b) Eivgi, O.; Lemcoff, N. G. Synthesis 2018, 50, 49.

(4) (a) Hoveyda, A. H. J. Org. Chem. 2014, 79, 4763. (b) Mu, Y.; Nguyen, T. T.; van der Mei, F. W.; Schrock, R. R.; Hoveyda, A. H. Angew. Chem. Int. Ed. 2019, 58, 5365.

(5) Pardatscher, L.; Hofmann, B. J.; Fischer, P. J.; Hölzl, S. M.; Reich, R. M.; Kühn, F. E.; Baratta, W. ACS Catal. 2019, 9, 11302.

(6) Guthertz, A.; Leutzsch, M.; Wolf, L. M.; Gupta, P.; Rummelt, S. M.; Goddard, R.; Farès, C.; Thiel, W.; Fürstner, A. J. Am. Chem. Soc. 2018, 140, 3156.
(7) (a) Lan, X.; Wang, T. ACS Catal. 2020, 10, 2764. (b) Sánchez, M. A.; Torres, G. C.; Mazzieri, V. A.; Pieck, C. L. J. Chem. Technol. Biotechnol. 2017, 92, 27.

(8) Schuster, C. H.; Dropinski, J. F.; Shevlin, M.; Li, H.; Chen, S. Org. Lett. 2020, 22, 7562.

(9) Park, K.; Padmanaban, S.; Kim, S. H.; Jung, K. D.; Yoon, S. ChemCatChem 2021, 13, 695.

(10) Schwab, P.; Grubbs, R. H.; Ziller, J. W. J. Am. Chem. Soc. 1996, $118,100$.

(11) Öztürk, B. Ö.; Öztürk, S. Mol. Catal. 2020, 480, 110640

(12) Zieliński, G. K.; Majtczak, J.; Gutowski, M.; Grela, K. J. Org. Chem. 2018, 83, 2542.

(13) Huang, J.; Stevens, E. D.; Nolan, S. P.; Petersen, J. L. J. Am. Chem. Soc. 1999, 121, 2674.

(14) Calderon, S. N.; Izenwasser, S.; Heller, B.; Gutkind, J. S.; Mattson, M. V.; Su, T.-P.; Newman, A. H. J. Med. Chem. 1994, 37, 2285.

(15) Nakajima, T.; Sunagawa, M.; Hirohashi, T.; Fujioka, K. Chem. Pharm. Bull. 1984, 32, 383.

(16) Öztürk, B. Ö.; Durmuş, B.; Karabulut, Şehitoğlu. S. Catal. Sci. Technol. 2018, 8, 5807.

(17) (a) Peil, S.; Guthertz, A.; Biberger, T.; Fürstner, A. Angew. Chem. Int. Ed. 2019, 58, 8851. (b) Biberger, T.; Zachmann, R. J.; Fürstner, A. Angew. Chem. Int. Ed. 2020, 59, 18423.

(18) Peil, S.; Bistoni, G.; Goddard, R.; Fürstner, A. J. Am. Chem. Soc. 2020, 142, 18541. 